\title{
Animals in the Kingdom of Ends
}

\author{
Heather M. Kendrick \\ Department of Philosophy and Religion \\ Central Michigan University \\ field2hm@cmich.edu
}

\begin{abstract}
Kant claimed that human beings have no duties to animals because they are not autonomous ends in themselves. I argue that Kant was wrong to exclude animals from the realm of moral consideration. Animals, although they do not set their own ends and thus cannot be regarded as ends in themselves, do have ends that are given to them by nature. As beings with ends, they stand between mere things that have no ends, and rational beings that are ends in themselves. I propose a broader version of Kant's kingdom of ends, in which rational beings respect the ends of all other beings that have them, including animals. The moral status of animals would still be dependent on the existence of rational beings, but our duty to take their ends into account would be a direct duty to them, rather than being a covert duty to human beings.
\end{abstract}

\section{Introduction}

Immanuel Kant holds that we have no duties to animals, because they are not ends in themselves, that is, autonomous beings of intrinsic value. Instead, we have indirect duties with regard to them. We ought not treat them cruelly, as it damages our natural sympathies and thus can harden us in our dealings with other human beings. He uses the example of a man who has his dog shot when the animal is no longer of service; this is not a violation of any duty to the dog, but of his duty to cultivate "the kindly and humane qualities in himself, which he ought to exercise in virtue of his duties to mankind" (Kant 1997b 27:459). Thus our duties with regard to animals are actually duties to human beings. We may kill animals if it is done humanely, and put them to work if it does not strain their capacities; in other words, we can use them as means to our ends, but we must avoid being cruel as we do it (Kant 1996b 6:443, 1997b 27:458-460).

The indirect-duty theory is usually considered unacceptable by those seeking a robust account of human obligations to animals, for 
various reasons. (I have previously discussed some of the reasons in more detail; see Fieldhouse [2004].) I will argue that animals can be given a higher moral standing while leaving most of Kant's ethical framework intact.

\section{Korsgaard's Kantian Direct-Duty Theory}

The obvious approach to forming a Kantian theory of direct duties to animals would be to claim that Kant should instead have recognized animals as ends in themselves. This is essentially the route taken by Tom Regan in his broadly Kantian approach to animal ethics, but insofar as he was successful it was by reconstructing the end in itself into a new concept of moral personhood that he calls "subject-of-a-life" (2004). Whatever the merits of this position, it makes no claim of being a truly Kantian position. The concept of the end in itself is one of the pillars of Kant's ethics, and it cannot be altered or replaced without substantial revision of other aspects of Kantian doctrine.

On the other hand, Christine Korsgaard claims that "end in itself" as described by Kant can be understood to include animals. She argues that the aspect of ourselves that we value, when we regard ourselves as ends in ourselves, is not only our rational nature, but also our animal nature. What differentiates the good for an animal from the good for an object such as a car, is that an animal has a natural good that matters to it, just as a human-qua-animal has a natural good that also matters to him or her. Korsgaard holds that a good "matters" to a being when that being "welcomes, desires, enjoys, and pursues its good" (Korsgaard 2005, 103). As legislating moral agents, we legislate for that natural good by promoting things that preserve our bodily lives, and forbidding things that harm, terrify, or destroy us; thus as moral arbiters of the universe we have declared our animal nature to be valuable (104). "Animal nature is an end-initself, because our own legislation makes it so" (106).

Although I am in agreement with the general theme of Korsgaard's interpretation, I believe she has erred in elevating 
animals to the status of ends in themselves. Being an end in itself has two facets, which are closely related. The first is that an end in itself is never a mere means, and cannot be used as a tool to achieve other ends (Kant 1996b, 4:428); this is sense of "end in itself" addressed by Korsgaard's argument. (All references to Kant are to the Akademie marginal pagination.) The second is that an end in itself is itself a source of ends, an autonomous legislator (Kant 1996b, 4:435). These are not independent ways of being an end in itself; the first is dependent on the second, as it is our status as moral legislators that makes it impossible for us to be merely a means and so forbids others from treating us as such: "morality is the condition under which alone a rational being can be an end in itself, since only through this is it possible to be a lawgiving member in the kingdom of ends. Hence morality, and humanity insofar as it is capable of morality, is that which alone has dignity" (Kant 1996b, 4:435). The law determines the worth of various things, relative to each other, but the lawgiving itself has infinite worth; thus it is our moral dimension that makes us ends in ourselves (Kant 1996b, 4:435-436; cf. 4:437-438). Kant regards autonomous legislation as both necessary and sufficient for a being to have a dignity rather than a price, that is, to be an end in itself rather than a means. Kant's intention is not to show that autonomy is one possible criterion, but that it is the only possible criterion; this is evidenced when Kant claims that ". . .morality is the condition under which alone a rational being can be an end in itself . . ." and that "... humanity insofar as it is capable of morality is that which alone has dignity..." (Kant 1996b, 4:435). Everything else can be used merely as a means (Kant 1996a, 5:87).

Korsgaard's claim that animals are ends in themselves does not, therefore, sit well with Kant's theory. If we confine ourselves to just the first sense of "end in itself" (something that is not a mere means) then we might include animals in it, but we would need a whole new explanation of what justifies declaring anything, human or animal, an end in itself. The fact that we both have a natural good that matters to us is not enough to show that this forbids our use as means. More work would need to be done there and, like Regan's view, it would 
entail a wide divergence from Kant. Kant has an internally coherent justification for granting humans this status, but it is one that cannot be extended to animals. In the interest of showing that Kant can accommodate a more robust theory of duties to animals while doing as little violence to the rest of his ethical theory as possible, I must reject Korsgaard's claim that animals are ends in themselves.

Like Korsgaard, I will argue that the assignment of value by rational beings is what gives rise to our obligation to take nonrational beings into account in our moral legislation. My starting place will not, however, be our shared animality. I find two weaknesses in that approach. First, as Korsgaard herself acknowledges (Korsgaard 2005, 100n), when Kant discusses our duties to ourselves with respect to our animal nature, all the examples ultimately demonstrate that abusing our animal nature is bad because in doing so we also abuse our rational nature. Thus Kant is showing that it is our rational nature, not our animal nature, that exists as an end in itself. Korsgaard is willing to diverge from Kant on this point. I would be, too, but her argument has not provided a compelling reason to do so. Second, Korsgaard has not successfully shown that in legislating for the protection of our animal needs, that it is the animality we are valuing. Instead, one could argue that what is being valued is the autonomy of rational beings, first by preserving our lives (a necessary precondition for preserving our autonomy), and second by protecting our right to pursue private ends related to our animal nature, as long as they do not interfere with others' right to do the same.

\section{Animals as Subjects in the Kingdom of Ends}

In rejecting the claim that animals are ends in themselves, it may seem that I have eliminated any possibility of anything more than indirect duties with respect to animals. The end in itself is the center of Kant's ethics and the source of all value. How can there be any room left for animals? I believe that the answer lies in Kant's idea of the Kingdom of Ends. 
Kant offers three main formulations of the categorical imperative. The first uses the criterion of universalizability, and the second commands that we treat humanity as an end in itself. The third introduces the idea of a Kingdom of Ends, which Kant describes as "a whole of all ends in systematic connection (a whole both of rational beings as ends in themselves and of the ends of his own that each may set himself)" (Kant 1996b, 4:433). In other words, it is the idea of a world in which all the ends of rational beings are respected and none are in conflict. In such a world, all rational beings are both legislators and subjects of the law. We should judge our own actions by whether they would accord with this harmonious kingdom of ends. Kant formulates this as "act in accordance with the maxims of a member giving universal laws for a merely possible kingdom of ends" (Kant 1996b, 4:439).

Although it is not entirely clear that the three formulations of the categorical imperative are equivalent as Kant claims, they are certainly interrelated. The formula of universalizability uses the form of the law as a measuring stick and the formula of humanity uses the matter of the law. The Kingdom of Ends synthesizes the two into one concept in which form and matter unite, resulting in a world of universal laws that respect and protect the ends of all rational beings. It is not hard to see why the Kingdom of Ends has appealed to many recent commentators. Its incorporation of the previous two formulations makes it the richest conception of the categorical imperative that Kant offers. Although Kant assures us that all the formulations express a single categorical imperative, the formula of the Kingdom of Ends makes it easier to see how the formula of universal law and the formula of humanity work together.

Kant identifies two roles for persons in the Kingdom of Ends. Every rational being is either a member or a sovereign. Members both legislate, and are subject to universal laws; this is the category that we as human beings fall into. A sovereign, on the other hand, would be a rational being who legislates without being subjected to anyone else's will; this is possible "only in case he is a completely 
independent being, without needs and with unlimited resources adequate to his will" (Kant 1996b, 4:434). God would presumably be such a being; elsewhere Kant explains that the concept of duty does not apply to a holy will, a claim that he also makes for the sovereign of the Kingdom of Ends (Kant 1996b, 4:434). Everything that is not a member or a sovereign is merely a thing, to be used as a means for rational beings to achieve their ends.

The Groundwork implies that animals have no place in the Kingdom of Ends apart from their usefulness to rational beings. Beings without reason "have only a relative worth, as means, and are therefore called things" (Kant 1996b, 4:428). Animals, then, must be things. (This would hold even if Kant were to acknowledge that some animals have degrees of rationality, because the rational capacity that concerns Kant in these passages is the ability to act according to principle, a capacity which even the most intelligent animals lack.) Kant sharply divides the Kingdom of Ends into persons and things; the former have dignity, the latter merely a price. Because animals cannot participate in the Kingdom as legislators, they are not members and their ends are not taken into account in the systematic unity.

Kant's political analogy lacks an obvious group that can exist in a natural kingdom - that of the subject, who is governed (and, ideally, protected) by laws but cannot legislate them. Kant may have seen this role as being filled by things, but I believe that subjects are distinct from things. Subjects are beings whose interests are taken into account by the laws that members and sovereigns enact, even though they do not participate in legislating those laws; in a worldly government, this would typically include children, the severely mentally impaired, and so on. (It also often includes resident aliens, but that category does not carry over into the Kingdom of Ends, which has no such territorial boundaries.) Laws can be enforced on their behalf. This is the legal equivalent of moral patienthood. Things, on the other hand, have no interests of their own (although we may have an interest in them) so it would not make sense to 
legislate on their behalf. Extending the political metaphor that Kant uses in discussing the Kingdom of Ends, I will use the term "subject" to describe those who would have the status of moral patients in the Kingdom of Ends.

Kant does not acknowledge the existence of subjects in the Kingdom of Ends. He does, however, make reference to the idea of a subject when discussing why human beings must be subject only to laws that we give ourselves. Human beings are autonomous, and thus in the Kingdom of Ends cannot be mere subjects. If we were subject to the law without being its originators, then the law must compel us by some external means, that is, heteronomously (Kant 1996b, 4:433). Thus the law must be one that we give ourselves. Being both subject to and legislator of the law is what gives us the status of member in the Kingdom of Ends.

Animals cannot be moral legislators because they are incapable of acting according to self-originated principles; thus they cannot be members in the Kingdom of Ends. They also are not subject to the law. We no longer put animals on trial or execute them for crimes; we may kill a dog that has injured people, but we do so for reasons of safety, not justice. We consider it appropriate to constrain an animal's behavior according to relevant laws, but it is the animal's guardian that is truly subject to the law. A dog does not understand that it is not permitted to foul the sidewalk, but we still have laws against that behavior and we expect the dog's guardian to compel it to act in a certain way. This can be carried over by analogy into the ideal Kingdom of Ends. Since animals are not internally motivated to follow the law by reason, they may be externally compelled in certain ways by the members of the Kingdom. The law would be addressed to the moral agents responsible for them, not to the animals themselves. In a way animals are subject to the law, in that we can legislate certain restraints on their behavior. But this is not really the same sense in which a moral agent is subject to the law, because the agent can understand the law and act accordingly. An animal can be compelled physically or psychologically to act a certain way, but will 
usually be responding to something unrelated to the law. The agent, on the other hand, can be motivated by the law itself. Animals are a subject of the law, rather than being subject to the law.

In some cases, animals may be capable of understanding a law. Kanzi the bonobo and Alex the African gray parrot are famous cases of animals that have been taught to use language. This implies a capacity for conceptual thought. Some animals also engage in deceptive behavior, which could suggest the capacity to attribute beliefs and intentions to others (though this is controversial, as the behavior may be explicable without the animals having such a theory of mind). Animals that have such advanced reasoning capacities might be able to recognize and understand laws. This would likely apply only to a small number of animals as special cases. Even those animals that do understand a law would still not be lawgivers in the kingdom of ends, as they would not be capable of generating laws according to rational principles. This gray area points to the fact that rationality is not the all-or-nothing state that Kant regarded it to be.

Animals, I argue, should be regarded as subjects in the Kingdom of Ends, and we must legislate on behalf of them and in their best interests. In order to make this argument, I will need to establish two main claims. First, that animals have interests in a way that things do not; and second, that those interests should be considered by the legislators of the Kingdom of Ends.

\section{How Animals Have Interests}

A being with interests, as I use the term, is one that has ends that matter to it. Having ends is a quality that animals share with human beings (and by extension other rational beings), and that they do not share with anything else. This is because having ends implies a power of choice. Things like tables and cars have ends only metaphorically or by extrapolation of the human ends involved with them. Plants are a harder case, as they seem to have ends that lead them to grow toward a light source and other basic movements. But Kant does not attribute a power of choice to plants (whereas he does 
attribute a power of choice to animals [Kant 1997a, A 534/B 562]), and I see no reason to disagree. The power of choice is a mental faculty, and it is implausible to attribute mind to plants as we do to animals.

It is possible that one could argue that plants possess a low-level calculating function that governs their heliotropic behavior, and that is different only in degree from the basic weighing of inclinations that is involved in the animal power of choice. Or, one could argue that it is possible to build a machine that mimics the animal power of choice in its ability to select between options in the pursuit of goals (which we would then perhaps be justified in calling "ends"). If machines and plants also have ends, then the apparently special status of animals and the importance of ends is diminished.

Even if I did acknowledge such similarities between animals, plants, and machines, animals' ends would still be of a different kind, because their ends matter to them - that is, it matters to them whether those ends are achieved or frustrated. An animal is, as Korsgaard puts it, "an organic system to whom its own good matters" (Korsgaard 2005, 103). Things can go well or badly for it in a way that things cannot go well or badly for a table or a car, or even a tree.

Of course, there is a sense in which things are "good for" a table or car. It is good for a wooden table to be oiled periodically, and bad for it to be sat upon by a heavy person; it is good for a car to have proper oil pressure, and bad for it to be exposed to a lot of salt. In a biological sense, various things are good or bad for trees. But these things do not capture what I mean for something to "go well or badly" for a being.

Kant's argument for indirect duties to animals itself rests on an intuition that animals' ends matter to them. Why is it that he identifies mistreatment of animals as something that damages our humanity, but not mistreatment of carriages or tables? (Likewise for plants; although he does argue that it is a duty to avoid wanton 
destruction of natural beauty, his reasons for this are separate from his reasons for avoiding cruelty to animals, and he regards the latter as "far more intimately opposed" to our duty [Kant 1996c, 6:443].) Kicking the wheels of a carriage or taking a hatchet to a table might be foolish, but it does not damage our humanity as would kicking a horse's legs or taking a hatchet to a dog. Why not? It cannot be just that the objects do not resemble human beings enough, because on the surface an animatronic pirate at Disneyland resembles a human being a lot more than a dog does, yet no one would suggest we have duties with respect to animatronics.

The answer lies in Kant's own remark about why we have duties with respect to animals: because cruelty "dulls his shared feeling of their suffering" (Kant 1996c, 6:443). Tables and animatronics do not suffer; that is, they do not experience suffering. There is no feeling there for us to share. But when one kicks a dog, the dog suffers; kicking it is not just bad for it, it is bad for it in a way that matters to it, because it is conscious. The belief that animals are conscious is implicitly acknowledged by Kant in his theory of indirect duties. Because they are conscious, animals have ends that matter to them, a characteristic they share with human beings but that sets them apart from things; I term this "having interests."

\section{The Value of Happiness}

Showing that animals have interests at least gives a possible criterion that allows them to be separated from mere things in the Kingdom of Ends. However, it is not sufficient to establish that these interests must be taken into account by the members of the Kingdom. I will argue for this further claim by discussing the value of happiness.

In the Critique of Practical Reason, Kant defines "happiness" as "the state of a rational being in the world in the whole of whose existence everything goes according to his wish and will" (Kant 1996a, 5:124). By limiting this to rational beings, he seems to exclude the possibility that animals can be happy at all. 
Why would rationality be required for happiness? The apparent limitation might simply be due to context, since he is discussing rational beings in the passage. Or it could be that somehow happiness is dependent on the possession of a will (Wille). It is true that animals do not have a will (Wille) as this is limited to fully rational beings; however, animals do have a power of choice (Willkür). Insofar as an animal is able to obtain the objects of its power of choice (which might be described as having things "go according to its wishes"), this would seem to fit Kant's definition of happiness. Happiness for a human being would be different from happiness for an animal, since the former would involve the rational will and the latter a merely animal power of choice, but both could fall under the general term "happiness."

Perhaps it is not the fulfillment of every individual desire that constitutes happiness, but the satisfaction of knowing that all one's desires have been fulfilled; this would require a higher-order ability of reflection than most, if any, animals possess. It would seem to require reason, although not necessarily the moral component of reason. It is moral reasoning that animals conspicuously lack, whereas some other aspects of reason are apparently present. So it is possible that some of the most intelligent animals have the ability to conceptualize that their desires have been satisfied. Still, the requirement that a creature be able to reflect on its own satisfaction would exclude almost all, if not all, animals from being capable of happiness.

The more general definitions of happiness that Kant gives in the Groundwork - "that complete well-being and satisfaction with one's condition" - (Kant 1996b, 4:393), and "the entire satisfaction of [needs and inclinations]" (4:405) - do not make reference to rationality as a requirement for happiness, although they do not rule out that claim either. If Kant does incorporate a requirement for rational reflection into his concept of happiness at times, he does not do so consistently: when discussing the use of practical reason to further one's happiness, Kant states that a person's reason "... does 
not at all raise him in worth above mere animality if reason is to serve him only for the sake of what instinct accomplishes for animals. . ." (Kant 1996a, 5:51-62). Given the context, it is plausible to take "what instinct accomplishes in animals" to be the attainment of happiness.

The solution, I believe, is in the following passage: ... as far as our nature as sensible beings is concerned, all that counts is our happiness if this is appraised, as reason especially requires, not in terms of transitory feeling but of the influence this contingency has on our whole existence and our satisfaction with it. . . (Kant 1996a, $5: 61)$.

Two important points can be gleaned from this passage. First, that Kant acknowledged a broader definition of happiness under which it is possible to evaluate it in terms of transitory feeling (which animals certainly possess). Second, that rational beings always evaluate their own happiness by seeing how the satisfaction of particular desires fits into their well being as a whole. I take this to mean that for beings that are capable of reflecting on the fact that their needs have been met, this reflection is part of their happiness, but that this ability to reflect is not required for beings that do not reflect in this way. This would explain why it is more difficult for humans to be happy than for animals; our happiness has an additional requirement that animals' does not.

According to Kant, happiness is not in itself good, but only in combination with a good will, which "seems to constitute the indispensable condition even of worthiness to be happy" (Kant 1996b, 4:393). Kant thus defines virtue as worthiness to be happy, and states that the highest good of a possible world is for happiness to be distributed in proportion to virtue (Kant 1996a, 5:110). This is similar to the idea of the Kingdom of Ends, with the addition that we must postulate God in order to ensure that happiness actually is distributed in proportion to virtue, since that does not necessarily happen in nature. 
Since happiness in proportion to virtue is the highest good, we must make the happiness of others our end. This would apparently not include animals, because animals, as they are not moral agents, lack virtue. They cannot, therefore, be worthy to be happy, as Kant has described it. On the other hand, they are not deserving of unhappiness, either. Their happiness is simply irrelevant, except insofar as our indirect duties require us to preserve it for our own ends.

Kant argues that happiness is not good in itself because, without the influence of a good will, it can give rise to boldness and arrogance (Kant 1996b, 4:393), and because we dislike seeing immoral people enjoying happiness, and only approve of it when it is had by virtuous people (4:393). Thus only when paired with the one thing that is good in itself - a good will, which animals cannot have - does it have value.

Kant's argument suffers from a flaw: if happiness cannot be judged on its own merits, apart from the presence of a good will, then why is it that we take pleasure in the happiness of a virtuous person, but displeasure in the happiness of an evil person? We base this evaluation on the belief that a good person deserves happiness, and a bad person does not. How do we know what a good person deserves? The concept of desert involves some sort of equivalence between the character of the agent and the quality of the thing that is deserved. Good people deserve good things. So in order to declare that good people deserve happiness, we must already have judged happiness to be a good (not necessarily the highest good, but a good nonetheless). There must be some sense in which happiness is a good independent of the presence of a good will.

If happiness is a good, then why is it that in some situations, such as those Kant mentions, we do not judge it to be good? Doesn't the fact that we dislike seeing evil people happy suggest that it achieves its goodness only when combined with virtue? I admit that there is a relationship between virtue and worthiness to be happy, but it is complex. If our intuitions reveal that there is something wrong 
with virtuous people being unhappy or evil people being happy, they also reveal further wrinkles. A small child happy at play is a sight that meets with almost universal approval; conversely, nothing is more upsetting than the sight of a child in distress. Yet a child, prior to the age of reason, is incapable of morality. Our judgment that children should be happy is not based on the child's moral character.

Whenever children are raised as an example in moral philosophy, the first inclination is to treat them akin to moral agents because of their potential to become moral agents. One could argue that children have the potential to become virtuous, and thus are worthy to be happy. Potentiality, however, does not solve the current problem. Children have the same potential to become evil as to become good. This would seem to imply either that the two cancel either other out, and children should be neither happy nor unhappy, or else that both are entailed, and the child should be made both happy and unhappy (perhaps alternately). We have no justification to assume that a child is going to become good (nor, of course, that it is going to become evil).

What is behind our intuitions about the happiness of children? Why is the happiness of a child so cherished, and the misery of a child so disdained? The answer, I believe, lies in the concept of innocence. As pre-moral beings, young children can do no evil. It is the lack of evil that we regard as the prerequisite for happiness, not the presence of moral goodness. In a rational adult, the lack of evil entails the presence of moral goodness; in a nonrational or pre-rational being, neither is present.

This also applies to our evaluation of happiness in animals. We take pleasure in animals' happiness, just as we have a shared sense of their suffering. The sight of happy animals at play does not produce as strong a reaction as the sight of happy children (no doubt for natural reasons related to the propagation of the species), but we do approve of it. We have a sense that animals are innocent, that they do nothing (morally) wrong, and although we may resent their 
presence at times, when we are thoughtful and objective we do not blame them when their actions have a negative impact on us.

I believe that it is not virtue that makes one worthy of happiness, but the lack of vice. Rather than the presence of virtue making happiness good, it is the presence of evil that ruins it, robbing it of its prima facie goodness. But what grounds this goodness? As moral agents, we necessarily confer value upon it. Kant states that happiness is the "... one end that can be presupposed as actual in the case of all rational beings. . . and therefore one purpose that they not merely could have but that we can safely presuppose that they all actually do have by a natural necessity" (Kant 1996b 4:415; cf. Kant 1996a, 5:25). As finite, rational beings - i.e. human beings - we necessarily regard happiness as valuable. Although it is our own happiness that nature instructs us to cherish, as rational beings and members of the Kingdom of Ends, our adoption of happiness as an end confers value upon it and thus we legislate for its general promotion. Korsgaard points out that Kant is not a value realist. That is, he does not believe there are intrinsically valuable things or qualities, which we then discover and arrange our morality around. Instead, as moral legislators we are the source of value (Korsgaard 18).

Since happiness is a natural end of all finite, rational beings, it has a value that we confer upon it. We see it as a prima facie good, and so we seek to promote it wherever it appears, except when it is tainted by evil. It is not, for the reasons Kant shows, absolutely good, and it is not the source of value; rather, rationality is the source of value, but as rational beings we place a value on happiness.

But when we take happiness as a value, why do we make an exception for immoral persons? All human beings have their own happiness as an end. As rational beings, we are supposed to evaluate all our actions as though we were legislators in the Kingdom of Ends, in which everyone's ends are in harmony. Thus, our own actions must promote, and not interfere with, the happiness of others. When rational beings interfere with others' ends, they are trying to make an 
exception of themselves. They will that their own ends should be met while others' are frustrated, but no consistent law can be made from this in the Kingdom of Ends. Thus in the real world, when we see such people being happy, we recognize the inconsistency between their willing unhappiness for others but receiving happiness for themselves, and this offends our rationality. In the case of children and animals (as well as those with a good will), happiness entails no inconsistency in will, and thus the value we confer upon it is not forfeited.

This argument does not contradict Kant's claim that the only thing good in itself is a good will. I have argued that happiness can be evaluated as a prima facie good independent of whether it is attached to a good will, but its value still comes ultimately from its endorsement by the human will, and so its good is still derivative rather than inherent.

Kant's own remarks about the good will fit well with my claim about the prima facie value of happiness:

Understanding, wit, judgment and the like. . . are undoubtedly good and desirable for many purposes, but they can also be extremely evil and harmful if the will which is to make use of these gifts of nature. . . is not good. It is the same with gifts of fortune. Power, riches, honor, even health and that complete well-being and satisfaction with one's condition called happiness, produce boldness and thereby often arrogance as well unless a good will is present which corrects the influence of these on the mind. . . (Kant 1996b, 4:393)

Note that Kant claims that it is the presence of an evil will that renders some talents of mind and qualities of temperament harmful, and then remarks that the same is true of happiness. Furthermore, he says that the reason a good will must be present in conjunction with happiness is that it will correct its influence on the mind. In an animal, no evil will can be present, and thus no correction is required. Kant's remarks in this passage support my claim that it is 
the absence of an evil will, rather than the presence of a good will, that is the important factor in judging worthiness to be happy.

Human beings can, and in fact must, have ends other than their own happiness. Animals, as nonmoral, are always concerned ultimately with satisfying their own needs, and thus with happiness. Taking account of animals' interests in the Kingdom of Ends would mean providing for their happiness. Since we have acknowledged happiness as valuable provided it is not accompanied by an evil will, we should legislate on behalf of animals in the Kingdom of Ends. Their status would be that of subjects, protected by the laws but not participating in their creation. This expanded view of the Kingdom of Ends allows us to see where Kant should have placed moral patients such as animals.

\section{How this Theory Differs from Kant's Indirect-Duty Theory}

It might be objected that what I have proposed is simply an indirect duty view under another guise, and thus that it is subject to all the same problems that many commentators have identified with that view. Since animals are not ends in themselves, it would seem that their ends, insofar as we are obliged to take them into account, are really ends for us. The duties that we have to promote their ends are not, however, merely covert duties to human beings. We must promote animals' happiness because happiness is valuable; and it is the happiness of that animal that we are obliged to promote, not some indirect effect on the happiness of human beings. Therefore, my view is not an indirect duty view as Kant's is. Animals, however, do have a status that is contingent on our own, and so our duties to them are not duties to them in quite the same way that our duties to human beings are. This is because it is not the animals that bind us in a relation of obligation; the source of the obligation is ourselves as rational beings. Our duties to other rational beings, on the other hand, are duties that originate in them as well as in ourselves. 
Since animals' moral status is dependent on the value that rational beings place on happiness, it might seem that our duties to animals are really only covert duties to ourselves, to respect our own values. (Note that this criticism would apply equally to Korsgaard, since she makes animals' status as ends in themselves dependent on the value that rational beings place on their animal nature.) I object to Kant's indirect duty view for several reasons, one of which is that animals' moral status is entirely dependent on human psychology, and so if it turned out that we could learn to separate our sympathy for animals from our sympathy for rational beings, there would be nothing wrong with torturing animals. My own view may seem to be equally contingent and open to a similar objection. We must provide for animals' happiness because we happen to value happiness in ourselves; thus, if we did not value happiness, we could harm animals as we wished.

Although it is true that my view maintains Kant's claim that only rational beings are ends in themselves, and thus the moral status of other beings is dependent on ours, it is not contingent in the same way Kant's is. Kant claims that happiness is "necessarily the demand of every rational but finite being" (Kant 1996a, 5:25). Although it is contingent in the sense that what constitutes happiness varies from person to person (and presumably would vary even more if we knew of any other rational but finite beings), it is subjectively necessary in the sense that as finite beings we have needs and these needs are necessarily incorporated into our desires (Kant 1996a, 5:25). Those desires, and the happiness that results from fulfilling them, are an inextricable part of our humanity. Happiness is bound up with our being not just rational beings, but also human beings. Furthermore, happiness is such an important value for us as finite rational beings, that its presence (in proportion to virtue) is necessary for the attainment of the supreme good. Linking animals' status to the value we place on happiness does not put them in the precarious position that linking their status to the promotion of sympathy does. My own position does not make the wrongness of cruel treatment of animals 
dependent on any effect that the treatment would have on the agent or on other human beings.

\section{Conclusion}

My intention has been to carve out a space for animals in Kant's moral theory by discarding his unsatisfactory account of indirect duties and replacing it with a theory that provides for a more robust conception of animals' place in the moral sphere. Although I have focused on animals, I believe that my conclusions will also help account for permanently nonrational human beings, such as those with severe developmental disabilities and those suffering from advanced Alzheimer's disease. In striving toward the Kingdom of Ends, we should take into account all beings with ends that matter to them. Although it may be equally consistent with the rest of his moral theory to simply deny that there is anything wrong with treating animals as cruelly as we wish, I believe that this violates Kant's attempt to create a moral system that accords with common intuition. In proposing the doctrine of indirect duties to animals, Kant seems to be trying to get them in through the back door; it is as though he wants to acknowledge the common intuition that we have duties to them, but has been trapped by his belief (which I do not dispute) that moral agency is the source of all moral value. His mistake, I believe, is in not recognizing that we can locate moral value in things other than ourselves: its source need not be the same as its location.

\section{References}

Fieldhouse, Heather. 2004. The failure of the Kantian theory of indirect duties to animals. J ournal for Critical Animal Studies 2, no. 2, http://www.criticalanimalstudies.org/?page_id=396 (accessed June 15, 2010).

Kant, Immanuel. 1996a. Critique of practical reason. In Practical Philosophy, trans. and ed. Mary J. Gregor, 137-271. Cambridge: Cambridge University Press.

Kant , Immanuel. 1996b. Groundwork of the metaphysics of morals.In Practical Philosophy, trans. and ed. Mary J. Gregor, 41-108. Cambridge: Cambridge University Press. 
Kant, Immanuel. 1996c. Metaphysics of morals. In Practical Philosophy, trans. and ed. Mary J. Gregor, 354-603. Cambridge: Cambridge University Press.

Kant, Immanuel. 1997a. Critique of Pure Reason. Trans. and ed. Paul Guyer and Allen Wood. Cambridge: Cambridge University Press.

Kant, Immanuel. 1997b. Lectures on Ethics. Trnas. Peter Heath and J. B. Schneewind. Cambridge: Cambridge University Press.

Korsgaard, Christine. 2005. Fellow creatures: Kantian ethics and our duties to animals. Tanner Lectures on Human Values 25: 77-110.

Regan, Tom. 2004. The Case for Animal Rights, 2nd edn. Berkeley: University of California Press. 